\title{
Antecedentes e expressões atuais da economia solidária
}

Antecedents and Current Expressions of the Solidarity Economy

Antécédents et expressions actuelles de l'économie solidaire

\section{Luiz Inácio Gaiger}

\section{OpenEdition}

\section{Journals}

Edição electrónica

URL: http://journals.openedition.org/rccs/401

DOI: $10.4000 /$ rccs. 401

ISSN: 2182-7435

\section{Editora}

Centro de Estudos Sociais da Universidade de Coimbra

\section{Edição impressa}

Data de publição: 1 Março 2009

Paginação: 81-99

ISSN: 0254-1106

\section{Refêrencia eletrónica}

Luiz Inácio Gaiger, "Antecedentes e expressões atuais da economia solidária », Revista Crítica de Ciências Sociais [Online], 84 | 2009, colocado online no dia 01 dezembro 2012, criado a 30 abril 2019. URL : http://journals.openedition.org/rccs/401 ; DOI : 10.4000/rccs.401 


\title{
LUIZ INÁCIO GAIGER
}

\section{Antecedentes e expressões atuais da economia solidária}

\begin{abstract}
O artigo examina as novas formas de organização e mobilização coletivas, atualmente observadas em escala global e associadas ao conceito de Economia Solidária. Apresenta suas singularidades e fundamentos comuns, comparando realidades e designações que demarcam antecedentes históricos da Economia Solidária ou gravitam em torno das práticas atuais de solidariedade, como a Economia Social e o Terceiro Setor. A análise considera as modalidades de ação correspondentes, em sua gênese e em suas orientações normativas, e destaca sua aptidão a preservarem a natureza plural da atividade econômica, em contraposição à racionalidade do mercado e da acumulação privada. Elas respondem a necessidades materiais e expressam uma rejeição da sociabilidade intrínseca à economia capitalista.
\end{abstract}

Palavras-chave: Economia popular, economia social, informalidade, solidariedade, terceiro setor.

A solidariedade no campo econômico volta à cena no umbral do século XXI. Ao Norte, destaca-se o dinamismo evidenciado pela Economia Social a partir dos anos 1980, com sua ênfase renovada na reciprocidade e no debate em torno das grandes questões da sociedade. Esses traços a aproximam da Economia Solidária da América Latina, hoje reconhecida e promovida como uma alternativa diante dos atuais modelos de desenvolvimento. Estudos demonstram que a eficiência econômica dos empreendimentos solidários é função dos seus dispositivos de eqüidade e de autogestão, irredutíveis à lógica instrumental que preside o agir econômico ordinário (Gaiger, 2007a; 2007c). Esse rol crescente de experimentações sinaliza a presença de práticas econômicas vincadas em princípios não utilitaristas, desprezadas pelo pensamento hegemônico não obstante contenham sociabilidades densas e se tenham mostrado historicamente decisivas à sobrevivência de amplos segmentos sociais. Faz-se necessário ampliar o cânone da produção e da circulação de bens (Santos, 2002). 
Há uma profusão de trabalhos sobre as novas manifestações da solidariedade, inúmeras questões e prismas de análise. ${ }^{1}$ Esse artigo tenciona contribuir para o conhecimento das singularidades e dos fundamentos comuns de tais experiências, considerando suas raízes históricas, ao Norte e ao Sul, e suas principais expressões atuais. No plano empírico, no Sul a atenção é dedicada à América Latina, fazendo-se do caso brasileiro extrapolações estimadas válidas para o continente. O contexto europeu servirá de contraponto ao Norte, sendo a França nesse caso a principal referência implícita.

As primeiras duas seções do texto retraçam em grandes linhas a gênese da Economia Solidária na Europa e na América Latina. Nas seções seguintes, ao cotejar o conceito de Economia Solidária com aqueles de informalidade, Economia Popular e Terceiro Setor, chega-se a um maior delineamento dessas experiências e a uma visão mais nítida sobre os contrastes e semelhanças entre os casos latino-americano e europeu. Ao final, discutem-se questões gerais atinentes à emergência e ao sentido da solidariedade, como elemento constitutivo da economia e da vida coletiva nos últimos dois séculos.

\section{A vertente social européia}

$\mathrm{Na}$ Europa, a Economia Solidária constitui de certo modo um novo capítulo da história da Economia Social, cujas raízes mais distantes datam do século XIX. Nesta época, face às turbulências sociais provocadas notadamente pela revolução industrial, o associativismo surgiu como uma resposta de operários e camponeses, caracterizando-se desde esses primórdios por formas de gestão autônomas e democráticas. Em tais iniciativas, as relações de poder e a repartição dos ganhos subordinavam-se ao primado das pessoas diante do capital e à finalidade principal de garantir benefícios aos membros. A rentabilidade econômica representava antes um meio do que um fim, orientando-se pelos objetivos sociais das organizações.

Desde então, a Economia Social forjou setores sócio-econômicos como as cooperativas, as mútuas e as associações, ao mesmo tempo em que ensejou movimentos sociais correlatos a esses campos de ação. Um traço distintivo dessas organizações foi combinar recursos provenientes do mercado, oriundos da venda e troca de bens e serviços, com recursos de natureza não mercantil, como as subvenções públicas e, ainda, com recursos alheios à lógica monetária, como as práticas de ajuda mútua (Defourny, 1998). A Economia

\footnotetext{
${ }^{1}$ Algumas revistas lançaram números especiais sobre o tema, úteis como visão panorâmica: Revista Ciências Sociais Unisinos (2001); Revue du MAUSS (2003); Revue Économie et Solidarité (2003); La Revue Nouvelle (2007); Revue Tiers Monde (2007); Revista Katálysis (2008).
} 
Social deixou assim manifesta a natureza plural da atividade econômica. Ela se opôs às tendências de redução da economia ao princípio do mercado e à racionalidade da acumulação privada. Com tais premissas, desempenhou um papel considerável na construção dos regimes do bem-estar social.

No limiar do século XX, a Economia Social começou a apresentar sinais de debilitamento. De um lado, o movimento operário perdeu aos poucos o seu élan mobilizador, por motivos contrapostos: ao mesmo tempo em que os duros confrontos com as forças dominantes minavam a resistência dos trabalhadores, seu ardor era afetado pelo avanço inelutável das relações capitalistas e por novas vias de saída, como a migração ao ultramar e a mobilidade ocupacional ascendente, favorecida pela expansão do mercado de trabalho. De outro lado, a Economia Social sofreu um processo de assimilação ao regime dual Estado-mercado. À medida que o mercado e o Estado foram assumindo suas funções de geração de riqueza e de assistência social, a solidariedade de tipo associativo recuou para um papel subsidiário. A institucionalização da Economia Social engendrou sua fragmentação e perda de unidade. As mútuas, sob controle do Estado, foram relegadas à função de dispositivos complementares dos sistemas de seguridade social. As cooperativas lançaram-se na economia de mercado, curvando-se para isso a seus preceitos e às formas mais adaptadas à sua sobrevivência nesse ambiente competitivo. Essas tendências, aliadas a processos de especialização e tecnificação dos organismos da Economia Social, resultaram no sufocamento gradual da sua dimensão política e combativa. Para tal arrefecimento colaborou enfim o menosprezo das facções que passaram a dominar o movimento operário, à custa do refluxo das correntes libertárias e de suas propostas de auto-organização.

Com a crise da regulação keynesiana, nos anos 1970, repercutindo diretamente sobre as funções de preservação do equilíbrio social típicas do Estado Providência, uma série de novas experimentações teve lugar, justificando a menção a uma nova economia social, conforme o termo empregado no Canadá: iniciativas locais no campo dos serviços sociais e de assistência a pessoas necessitadas, novas cooperativas, empresas de inserção, finanças solidárias, comércio justo, empresas em processo falimentar transferidas às mãos dos trabalhadores, etc. Renovada, a Economia Social passou a exercer um papel substitutivo dos arranjos precedentes no tocante ao mercado (criação de empregos, crescimento econômico) e ao Estado (redistribuição e regulação), aproximando-se da noção de Terceiro Setor, em voga a partir da década seguinte.

Como fatores de impulsão desse setor intermediário, podem-se sublinhar tanto a redescoberta de características comuns entre as forças cooperativas, 
mutualistas e associativas, quanto objetivos de financiamento e de representação junto ao Estado. Condições políticas ainda mais favoráveis apareceram com o avanço da crise do Estado Providência e com o colapso das experiências de socialismo centralizado (Defourny, 1998). Antes, já nos anos 1960, as viravoltas experimentadas nos padrões culturais e na vida cotidiana introduziram novas pautas e formas de engajamento. Autonomia e liberdade na esfera privada, qualidade de vida, implicação dos usuários e consumidores de bens e serviços, preservação do ambiente natural, novas relações entre sexos e gerações, pacifismo e outros temas ganharam destaque. Uma boa parte dessas questões, outrora intangível ou disciplinada por normas e práticas institucionalizadas, foi então denunciada por seu enquadramento conservador e burocrático.

Com o descenso progressivo das grandes ideologias políticas, as formas usuais de militância cederam espaço a envolvimentos que buscavam respostas a problemas específicos ou de interesse difuso, como a discriminação racial, a paz e a sobrevivência do planeta. A reconversão capitalista, ao provocar o aumento do desemprego e gerar novas formas de exclusão social, estimulou a busca de alternativas, para as quais concorreram indiretamente outros fatores: a evolução demográfica causada pelo envelhecimento da população, pelo novo perfil das uniões conjugais e pela progressão das atividades femininas; a valorização e multiplicação dos serviços de cuidados às pessoas; o incremento das desigualdades engendrado pela sucessão de políticas neoliberais e pelo modelo de globalização resultante (Laville, 2004).

Diferentemente do Terceiro Setor, a nova geração da Economia Social recusou-se a cumprir o simples papel de uma economia de reparação (Laville, 2004). Suas ações concretas e suas bandeiras atuais reclamam o caráter universal irrevogável dos direitos cidadãos e a necessidade de um novo sistema de regulação da economia. Ela refuta a separação entre as esferas social e econômica e a omissão dos seus vínculos recíprocos no debate político em torno dos modelos de sociedade. Seu olhar crítico sobre o silêncio da Economia Social precedente a respeito dessas questões, sua insistência quanto à dimensão política das iniciativas que promove e sua adesão aos movimentos altermundialistas conduziram vários dos seus defensores a designá-la de Economia Solidária, termo então predominante na América Latina.

Nem por isso os domínios em que a Economia Social se desenvolveu tradicionalmente devem ser negligenciados, pois em certos casos seguem demonstrando um dinamismo considerável, a exemplo do mutualismo direcionado ao campo da saúde. Entretanto, a Economia Social em sua configuração clássica mais ampla reveste-se de uma conotação bastante 
institucional e se defronta com problemas de isomorfismo que diluem as suas especificidades. Com o passar do tempo, ela englobou os ramos mais diversos do movimento associativo, diante dos quais tratou de propor uma via de convergência entre projetos de sociedade distintos, por vezes incompatíveis. Por isso, no imaginário social o termo não é unívoco e aponta tanto à assistência social quanto à mobilização cidadã em torno de uma ampla frente de lutas. Evocá-lo hoje de certo modo significa uma referência aos seus ideais fundadores, fato expresso na denominação híbrida de Economia Social e Solidária (Chopart et al., 2006), igualmente em uso como uma solução de compromisso entre seus promotores mais antigos e mais recentes.

Apesar dessas variantes, ${ }^{2}$ a experiência histórica da Economia Social na Europa, estendida ao campo recente das empresas sociais (Nyssens, 2006), permite constrastá-la com a noção bem mais estreita de setor sem fins lucrativos. A adoção dessa última nos países anglo-saxões, como sinônimo de Terceiro Setor, procura dar conta daquilo que, tendo um sentido social, envolve o setor privado, em si mesmo voltado ao econômico. A crítica necessária a essa redução arbitrária de toda lógica econômica à finalidade de lucro deixa mais salientes as diferenças de fato e de percepção entre a experiência norte-americana e a experiência européia (Evers e Laville, 2004) e favorece uma perspectiva comum Norte - Sul: melhorias nas condições de vida requerem a geração e a partilha de benefícios entre os membros dos empreendimentos solidários, o que supõe distinguir o lucro capitalista das demais formas de geração de excedentes. Além disso, as condições de gênese e de desenvolvimento das iniciativas demonstram importantes convergências entre os fusionamentos associativos ao Norte e ao Sul (Defourny et al., 1999). Por fim, a democracia nas organizações é um primado fundamental da Economia Solidária, o que não se aplica em extenso para o Terceiro Setor, que ademais tampouco questiona a dimensão estrutural das desigualdades e das transformações sociais necessárias à sua superação.

\section{A vertente popular latino-americana}

$\mathrm{Na}$ América Latina, o conceito de Economia Solidária refere-se essencialmente ao conjunto de iniciativas que, a partir da associação livre e democrática dos trabalhadores, visam ganho econômico e benefícios como qualidade de vida, reconhecimento e participação cidadã. A solidariedade diz respeito à cooperação na atividade econômica, à disponibilização para uso em comum dos meios de produção e à autogestão exercida na condução

\footnotetext{
${ }^{2}$ Para uma visão abrangente das nuances conceptuais, com referência principalmente à França, ver o número especial da Revista Alternatives Économiques: L'économie sociale de A à Z (2006).
} 
dos empreendimentos. As organizações de Economia Solidária minimizam a presença de relações sociais que subentendem a separação entre capital e trabalho. Ao convocarem os seus membros à participação cotidiana, motivam seu engajamento em problemas da comunidade e em lutas coletivas mais amplas. Tal como na experiência européia, as iniciativas de Economia Solidária na América Latina se valem de recursos e de relações mercantis, não-mercantis e não-monetárias. Elas igualmente rejeitam a excisão entre o econômico e o social e procuram reconciliar a eficiência com a cooperação produtiva (Gaiger, 2006).

As organizações de Economia Solidária compõem um quadro multiforme no continente. No Brasil, o seu primeiro Mapeamento Nacional, concluído em 2007, revelou que os 22 mil empreendimentos recenseados se dividem em duas categorias principais:

- Aqueles cuja atividade principal representa a fonte primordial de ocupação e de renda dos seus integrantes, desenvolvendo-se através de processos de socialização dos meios de produção ou de coletivização do trabalho. Incluem empresas autogestionárias recuperadas, grupos informais de produção, cooperativas agropecuárias e de trabalho, unidades de triagem de resíduos urbanos recicláveis e comunidades tradicionais, como pescadores e extrativistas.

- Aqueles cuja atividade coletiva principal aporta benefícios e serviços para as economias individuais ou familiares dos seus integrantes. Compreendem as associações de pequenos produtores rurais, centrais de comercialização, cooperativas de habitação, eletrificação e crédito, bancos populares, clubes de troca e hortas comunitárias.

O surgimento da Economia Solidária, nos anos 1980, dá continuidade e novo alento a uma história extensa, na qual se contam inúmeras experiências de solidarismo econômico entre os trabalhadores. Em cada região do continente, a Economia Solidária encontra antecedentes longínquos e próximos, a começar pelas formas autóctones pré-colombianas e pelos sistemas coletivos adotados pelos escravos libertos, cujo legado ainda resta avaliar. Essas múltiplas raízes e configurações, amplificadas pelos contrastes regionais e nacionais, tornam discutível adotar uma única conceptualização, muito embora grande parte dessas vertentes tenha confluído para expressões da solidariedade que hoje se reconhecem como parte de um grande movimento social e político, cuja unificação estaria em desejável estágio de construção. É fato que essas manifestações possuem efetivamente algo em comum quanto ao significado que assumem para os seus protagonistas diretos. Elas 
expressam a impossibilidade e a recusa de viver segundo os preceitos da economia capitalista e nos termos de sua sociabilidade intrínseca; em outras palavras, a negativa de abandonar sistemas de vida que não desvinculam as relações econômicas das relações sociais, insistindo em resgatá-los ou em agir por sua instauração.

Trata-se de uma resistência histórica orientada por valores cuja defesa se fez a duras penas e não impediu desvios de rota e importantes concessões. A maior parte dos países latino-americanos não chegou a conhecer um associativismo similar àquele do século XIX europeu, embora a vida comunitária tenha sido marcante em muitas regiões e propostas autogestionárias de organização tenham sido freqüentes no movimento operário ao menos até o advento dos regimes populistas, quando o Estado assumiu os rumos do desenvolvimento econômico e social. Com exceções momentâneas, as tentativas dos trabalhadores de construir alternativas pela via associativa não lograram converter-se em um movimento realmente classista, de contraposição à lógica do capital fundiário, comercial e industrial. Permaneceram dependentes da estrutura econômica regional, da cultura dos trabalhadores em questão e dos espaços encontrados nos jogos de poder.

Nas últimas décadas, a história econômica dos países latino-americanos variou menos do que sua história política. Uma população em franco crescimento demográfico, evadindo-se em grandes proporções para as cidades, deparou-se com a incapacidade de absorção pelo mercado formal de trabalho e com a falta de instrumentos para inserir-se estavelmente na economia formal. Compelido a sobreviver de trabalhos por conta própria e de ocupações temporárias informais, esse contingente modificou a paisagem urbana, expandindo os bairros periféricos pobres e convertendo a economia informal em um fenômeno de grande magnitude. A informalidade deixou de ser negligenciada apenas como um resíduo marginal do capitalismo, ou como um elemento funcional incorporado ao exército industrial de reserva, e passou a ser considerada um traço estrutural, irreversível no quadro solidamente instituído pelos modelos de desenvolvimento anti-sociais e excludentes.

Com o passar dos anos, o alastramento e a perduração da informalidade levaram a perceber que ela se inseria em estratégias mais amplas e que os setores populares mostravam-se capazes de se organizar e instituir novas frentes de mobilização. Em vários países, surgiram movimentos sociais nas periferias, de favelados e pobladores, lutando por moradia, serviços urbanos, renda e direito ao trabalho (Bell Lara, 1997). Iniciativas comunitárias se multiplicaram e despertaram o interesse paulatino de organizações como as Igrejas, inspiradas pela Pastoral de Libertação, e as instituições de micro- 
crédito, como os pioneiros bancos da mulher. Pipocaram comunidades de base, associações de moradores e uniões de produtores familiares, das quais surgiriam, nos anos 1980, as primeiras experiências coletivas de geração de renda, germes da Economia Solidária em muitos países da América Latina.

Nas atuais experiências de Economia Solidária, cabe ressaltar o fato de propiciarem vivências de trabalho de conteúdo axiológico e projetivo, que estimulam a formação de sujeitos (Veronese, 2008). Ao mesmo tempo, a Economia Solidária comporta uma dimensão política, dado que suas iniciativas promovem a participação, dinamizam redes de interação e ampliam a democracia nas comunidades em que se inserem. As práticas de autogestão, quando estendidas ao seu entorno, promovem a configuração de sistemas de reciprocidade e de espaços públicos de proximidade (Caillé e Laville, 1996). Esse alargamento da democracia para o terreno econômico, introduzindo nesse último uma racionalidade não mercantil nem estatal, depende igualmente da aglutinação das iniciativas de base, de modo a criar instâncias mais amplas de interlocução. É uma tarefa de projeção na esfera pública, de reivindicação e institucionalização, pela qual a Economia Solidária se constitui como um movimento social atuante no cenário político da América Latina (Gaiger, 2004a).

\section{Informalidade e economia solidária}

No contexto de ampla informalidade das economias latino-americanas, várias iniciativas de Economia Solidária prosperam sem deixarem de ser informais. Mas, nesse caso, os trabalhadores via de regra passam das suas modalidades usuais de economia para situações em que precisam controlar os fatores produtivos e ter em vista conseqüências futuras. Necessitam abandonar a percepção da vida como uma constante adaptação às circunstâncias e conceber a própria atividade como uma força suscetível de criar novas situações e influenciar o ritmo das transformações. ${ }^{3}$ Essa mutação é favorecida quando se utilizam os recursos dos indivíduos e de suas redes de relações, conseguindo explorá-los sem descaracterizá-los: opera-se uma metamorfose das relações de comensalidade, ancoradas nos laços pessoais e no costume, a uma lógica econômica propriamente empreendedora e solidária, sustentada em relações de cooperação (Razeto, 1990). Com esse substrato, as iniciativas de Economia Solidária assumem a perspectiva de superar a instabilidade e a incerteza que afetam a vida material dos pobres. Objetivam então reduzir

\footnotetext{
${ }^{3} \mathrm{Na}$ linguagem de Bourdieu (1963), passa-se de uma atitude de previdência, de resguardo diante do imprevisto, a um espírito de previsão das possíveis circunstâncias futuras, na intenção de agir antecipadamente.
} 
o grau de subordinação aos ditames da economia e ampliar as margens de retenção do valor excedente que produzem. Quando sacrificam para isso os próprios trabalhadores, o fazem mediante um esforço coletivo deliberado que por vezes posterga, sem descartar, futuras compensações advindas da consolidação do empreendimento (Gaiger, 2006).

Pobreza e informalidade acarretam limitações. Os empreendimentos solidários situados nas periferias urbanas se deparam com infindáveis dificuldades. Lidam com situações de enorme instabilidade material, de sociabilidades cambiantes nas quais os indivíduos, premidos pelas circunstâncias, vêem-se em regime de solidariedade forçada, sem conseguirem transformá-la em valor e em norma interior de vida. Quando se trata de agir coletivamente, impõe-se um desafio de envergadura, pois é necessário criar formas de sobrevivência em moldes desconhecidos, capazes de superar os obstáculos e gerar uma base social e material consistente. Os projetos coletivos contribuem então para a racionalização da solidariedade, uma vez que criam espaços para a sua prática intencional e cotidiana.

Informal, popular e solidário não são termos incompatíveis, mas tampouco indiferentes. A respeito da Economia Informal, fenômeno de fronteiras imprecisas, prevaleceu na América Latina um ângulo de análise limitado basicamente a destacar seu caráter reflexo e funcional para o capitalismo periférico e a interpretá-la como signo de carência e impotência dos setores sociais marginais. ${ }^{4}$ Tais setores foram considerados desprovidos de ação e de interesse pelas teorias críticas ao capitalismo. No âmbito das visões partidárias da economia de mercado, os setores informais foram convertidos em alvo de políticas de assistência e qualificação, com vista à sua futura inserção no mercado, via assalariamento ou na condição de microempreendedores. Carregaram o estigma da irracionalidade política, no primeiro caso, e da irracionalidade econômica, no segundo.

Posteriormente, a informalidade foi reinterpretada como parte da Economia Popular, na qual já se reconheciam uma lógica endógena e certa capacidade organizativa. Surgiram olhares muito mais favoráveis à economia dos pobres, vista nesta ótica como um prolongamento das solidariedades ordinárias, um canteiro de experiências e de formação de novos atores. Uma visão claramente otimista contrabalançou o descrédito das teorias precedentes sobre o informal. Mas incorreu em idealismo, por sua tendência a separar o informal e o popular em dois mundos e a valorizar unilateralmente

\footnotetext{
${ }^{4}$ Embora a informalidade tenha proporções menores nos países do Norte, a problemática chegou posteriormente a essa região, em função do quadro mais recente de exclusão social e de precarização das relações de trabalho.
} 
as expressões comunitaristas e combativas da Economia Popular, dissociando-as da ampla malha de práticas econômicas em que se situam, na qual também vicejam relações despóticas reprodutoras do individualismo e das desigualdades. Isto, à medida que na Economia Popular coexistem diferentes princípios de valor e os mais diversos arranjos destinados a assegurar a sobrevivência. Sendo determinada por necessidades de subsistência, limita-se principalmente à sua reprodução imediata, sem em princípio demonstrar capacidade de liberar-se da lógica econômica reinante. Seu horizonte primário é a sua inserção e reprodução no interior das determinações econômicas já instituídas.

Entretanto, como já apontado, tais limites não a impedem de funcionar também como um elemento de resistência de tais setores. A Economia Popular dispõe de um fundo de trabalbo (Coraggio, 2007), formado a partir de relações sociais que garantem a sobrevivência por meio de agenciamentos e de soluções práticas, diante das condições existentes. Esses ativos materiais e relacionais dos agentes econômicos populares precisam ser reconhecidos e potencializados em qualquer projeto de emancipação popular. Nesse sentido, a Economia Popular constitui um terreno primordial à construção, árdua e sujeita a reveses, da Economia Solidária.

\section{Economia solidária e terceiro setor}

$\mathrm{Na}$ América Latina, têm sido enquadradas no Terceiro Setor organizações de variadas origens e formas de atuação (Lisboa, 1999). De acordo com a definição canônica, igualmente adotada no Brasil, tais organizações possuem em comum o fato de atuarem em temas e questões de interesse público, sendo autônomas do ponto de vista de sua constituição, gestão e dissolução e estando desprovidas de ânimo de lucro. São entidades de direito privado que não buscam precipuamente gerar benefícios aos seus membros, habitualmente voluntários, mas sim responder a demandas coletivas, de comunidades ou de setores sociais específicos. Assumem então uma missão social determinada e a realizam com base em valores de gratuidade, confiança, respeito aos direitos humanos, igualdade, etc. Suas articulações se fazem por conexões horizontais descentralizadas, respeitando a pluralidade e as vocações singulares de cada organização.

Desse ponto de vista, há correspondências entre as estruturas e as lógicas de funcionamento do Terceiro Setor e da Economia Solidária. Em ambos os casos, as iniciativas primam por sua autonomia institucional e pela criação de redes, evitando estruturas piramidais e hierárquicas. Em sua atuação, múltipla, as afinidades maiores geram articulações mais estreitas e estas geram novas identidades, num processo contínuo de fusionamento e de 
recomposição. Formam uma realidade à parte, dotada de homologias estruturais e sistêmicas, bem como de vasos comunicantes, que as diferenciam do Primeiro e do Segundo Setores.

Entretanto, o amplo trânsito logrado pela expressão Terceiro Setor na América Latina tem a ver com a banalização do conceito, transformado em vade mecum por meio de procedimentos sujeitos a objeções evidentes: a) enquadrar em seu âmbito iniciativas das mais diferentes origens e naturezas, desprezando as impropriedades de tais inclusões e as contradições delas decorrentes, que retiram a unidade necessária para que tal realidade possa ser referida por um mesmo conceito; b) definir o Terceiro Setor por exclusão em relação ao Primeiro e Segundo Setores, o que faz tábua rasa dos contextos históricos e dos respectivos espaços reservados a iniciativas não privadas e não estatais, em franca desatenção ao caráter variável de umas e outras; ${ }^{5}$ c) desconhecer que a crise do Estado e as conseqüências da absolutização do mercado não estão desvinculadas de posições e estratégicas políticas, assumidas em parte pelos atores que hoje se perfilam ou são enquadrados nesta única rubrica. ${ }^{6}$

Com tal abrangência, o Terceiro Setor é inevitavelmente heterogêneo do ponto de vista político e ideológico, sobretudo em sociedades atravessadas por antagonismos de classe e sustentadas em pactos sociais tênues e pouco includentes. Se combinarmos critérios morfológicos e institucionais de classificação com uma abordagem interpretativa a respeito dos princípios e das lógicas de ação das organizações do Terceiro Setor, poderemos distinguir ao menos três subsetores em vários países latino-americanos:

- De um lado, um leque amplo de entidades associativas benemerentes, sem vínculos diretos com o fenômeno recente do Terceiro Setor. Compreendem organizações tradicionais de caráter filantrópico e assistencial, entidades corporativas ou comunitárias direcionadas à cultura ou lazer e, ainda, as demais instituições não estatais, a exemplo das cooperativas de consumo, dos hospitais e das escolas. Politicamente, essas iniciativas vinculam-se aos seus campos específicos de atuação, não

\footnotetext{
5 O hábito corrente de tudo classificar como sendo do Terceiro Setor teve possivelmente no Brasil um grande impulso na obra seminal de Fernandes (1994). A própria tentativa desse autor de refazer a história desse Setor projetando-o sobre realidades de outras épocas, altamente díspares, demonstra apenas que entre o Estado e o setor privado existiram sempre inúmeras outras formas de vida social, despojadas de qualquer unidade histórica e, por conseguinte, conceitual. Hoje ainda, para boa parte das organizações designadas do Terceiro Setor, essa catalogação soa estranha. ${ }^{6}$ Paradoxalmente, o Estado é um dos principais financiadores do Terceiro Setor, por seus aportes diretos e por outros mecanismos facultados às organizações privadas, na medida em que canalizam recursos para programas de natureza social.
} 
mantendo entre si senão uma identidade em sentido lato, o que lhes retira tanto os motivos quanto as possibilidades de ações conjuntas. Essa é uma das razões para a infreqüência e a escassa penetração do conceito de Economia Social na América Latina.

- De outro lado, as fundações e os institutos empresariais identificados com o conceito de responsabilidade social. Sua atuação normalmente complementa as políticas sociais, incidindo sobre questões incluídas no que essas organizações definem como agenda cidadã. Esse subsetor motiva as abordagens mais críticas sobre o Terceiro Setor, que o vêem como parte de um estratagema das classes dominantes, acionado por meio de mecanismos compensatórios que atenuam os custos sociais do modelo econômico neoliberal, com o fito de tornar tais custos suportáveis e evitar a eclosão de conflitos. Nessa ótica, o Terceiro Setor favoreceria a privatização da esfera pública e a deslegitimação do Estado, como espaço democrático primordial de transação de interesses e de seu atendimento por meio de políticas universais.

- Por fim, as organizações não-governamentais, ONGs, cuja atuação em geral se caracteriza pela promoção de iniciativas que tensionem e transformem as estruturas sociais. Nesse subsetor, encontram-se muitas organizações de fomento à Economia Solidária. Aqui, há uma questão importante a salientar: de uma função de apoio, exercida na retaguarda dos movimentos sociais, as ONGs passaram à linha de frente, outorgando-se o papel de atores da sociedade civil, em paridade com os próprios movimentos. A assimetria de forças entre as iniciativas populares e as ONGs suscita uma série de questionamentos sobre o papel dos agentes mediadores e sobre sua legitimidade, pois tendem a sobrepor-se aos empreendedores solidários, com o risco de sufocarem, uma vez mais, o protagonismo popular (Gaiger, 2005). ${ }^{7}$

Em termos mais gerais, caberia indagar se os fatores que dinamizam a sociedade civil e suas diferentes iniciativas, em suas relações com o mercado e o Estado, podem ser adequadamente compreendidos a partir da noção de setor, no sentido de um campo específico de práticas que se constrói por diferenciação e autonomia diante dos demais campos. Ao menos, essa visão da economia através de setores distintos, articulados segundo suas especificidades, não parece corresponder à experiência latino-americana. Seria

\footnotetext{
${ }^{7}$ No Brasil, as agremiações sindicais e as ONGs ganharam espaço nos últimos governos e têm recebido polpudas fatias do bolo público. Não seria exagero afirmar, em certos casos, que as ONGs converteram-se em um subproduto do setor estatal, se havendo institucionalizado sob sua estreita dependência.
} 
mais apropriada a noção de uma economia plural, em que coexistem diferentes iniciativas, híbridas no sentido de manejarem simultaneamente lógicas econômicas distintas e no sentido de possuírem uma dimensão social e política, integrada à sua atuação propriamente econômica. A natureza social ou não-lucrativa de algumas dessas iniciativas passaria a ser mais bem compreendida no interior dessa totalidade econômica, e não como uma propriedade de setores independentes. Nesse aspecto, entre outros, a experiência da América Latina aproxima-se mais da experiência européia do que do modelo norte-americano:

- Na América Latina, as iniciativas e as organizações que se situam fora do Primeiro e do Segundo Setores não podem ser equiparadas ao voluntary sector ou ao non-profit sector. À semelhança da Europa, no continente latino-americano desenvolveu-se um conjunto de organizações privadas voltadas à filantropia e baseadas no voluntariado. Mas isso não esgota as iniciativas sociais, que compreendem ainda as associações e cooperativas voltadas à provisão de serviços ou à produção econômica. As iniciativas econômicas contam basicamente com o trabalho remunerado de seus integrantes e buscam rentabilidade no mercado, embora o lucro e a acumulação do capital não sejam sua orientação determinante. Nesse campo, destacam-se em particular os empreendimentos de Economia Solidária, que se afastam assim duplamente dos conceitos de voluntary e de non-profit sector.

- Na América Latina tampouco há sentido em opor a Economia Solidária ao Estado e ao mercado. Mais correto é conceber a Economia Solidária como outra forma de produzir e de propiciar a circulação de bens e serviços, assegurando com isso a sobrevivência econômica e melhores condições de vida a seus participantes. Não se trata, portanto, de um setor que funcionaria sem relação com o mercado ou com a economia enquanto tal. Ao integrar-se a partir do campo econômico com outras iniciativas da sociedade civil, a Economia Solidária termina assumindo a defesa de melhorias nos serviços comuns e a promoção de garantias mínimas a pessoas desprotegidas, como se observa também na Europa. Não se justifica que iniciativas coletivas em prol do bem coletivo necessitem ater-se às organizações sem fins econômicos, desprovidas de qualquer motivação não-altruísta.

- A Economia Solidária não pode dispensar o Estado, pois esse constitui um alicerce para a sustentação inicial e o desenvolvimento ulterior dos mais diversos setores econômicos. Além disso, a viabilidade dos empreendimentos solidários requer princípios reguladores, no sentido 
de preservar uma efetiva democracia econômica. A esse respeito, a Economia Solidária se conduz como um ator coletivo, que se dota de uma identidade, formula princípios e programas de ação e institui estruturas representativas. Ela retoma um traço típico das sociedades insuficientemente institucionalizadas, nas quais as organizações dedicadas ao desenvolvimento econômico são compelidas à tarefa adicional de criar canais de comunicação e negociação entre os atores políticos, tanto do Estado quanto da sociedade civil. ${ }^{8}$

As semelhanças entre as experiências da América Latina e da Europa não anulam as diferenças. A começar, porque existem dois panos de fundo: lutar pela integração e lutar contra a desintegração. Ao Sul, a questão central consiste em garantir as condições materiais indispensáveis à sobrevivência de importantes contingentes, que jamais se integraram estavelmente na economia de mercado e no sistema de proteção social. Trata-se de lutar contra a pobreza e a miséria, de apoiar-se nas virtudes ocultas da Economia Popular para encontrar saídas de curto e médio prazo, sustentáveis. O que explica a importância atribuída ao tema das alternativas possíveis ao capitalismo, no sentido da construção de novas relações econômicas que não contenham processos de exploração e de reprodução das desigualdades. Ao Norte, trata-se antes de contrabalançar a crise do Estado do bem-estar, a obsolescência e a falta de mecanismos eficazes de regulação e proteção social, de reagir à exclusão social com base na energia contida na sociedade civil, na sua capacidade de iniciativa e de engajamento. Busca-se ativar a participação política, no interior de um sistema institucional enfraquecido em sua capacidade de oferecer respostas, mais ainda democrático e legítimo.

\section{O valor da experiência}

Por se referirem a contextos históricos específicos, esses prismas não impedem convergências entre a Economia Solidária ao Sul e ao Norte. A participação nessas experiências, tanto no plano das iniciativas locais quanto naquele das grandes movimentações altermundialistas, tem contribuído para a formação de identidades cosmopolitas, motivadas pela perspectiva de emancipação social (Santos, 2002). As práticas concretas de Economia Solidária verificam-se em diferentes contextos e possuem raízes às vezes

\footnotetext{
${ }^{8}$ Por outro lado, em resultado da preponderância ou do virtual monopólio do Estado na coleta e na redistribuição de recursos econômicos, observa-se uma sociedade civil lenta em estabelecer uma presença autônoma, mesmo em regimes democráticos (Gaiger, 2005).
} 
muito particulares, mas encontram unidade nessa partilha de valores e no horizonte de transformação histórica que as impulsiona.

Há prognósticos francamente otimistas, mas não faltam vozes discordantes. Uma linha freqüente de invectivas diz respeito aos limites congênitos da Economia Solidária: por ser parte integrante do sistema capitalista hegemônico e nele estar contida inexoravelmente, constituiria tão-somente um sinal de resistência momentânea, disruptiva em suas intenções, mas funcional ao sistema em seus efeitos históricos reais. Com tal premissa, a tarefa importante se resume a anunciar com clareza esses limites, sem interessar-se pelo significado do espaço deixado por eles ou pelas possibilidades de superar aquelas "coerções não inteiramente coagentes", na expressão de Edgar Morin. ${ }^{9}$

Algo importante a reter da teoria de transição de Marx é que componentes essenciais ao sistema capitalista nasceram e se desenvolveram dentro e durante a vigência do sistema feudal, não depois (Gaiger, 2007b). É necessário remover um obstáculo introduzido pela ciência crítica sucedânea de Marx, em seu afã de encontrar alternativas totais para o sistema imperante, compreendido por ela de forma cada vez menos dialética e mais monolítica: se a ruína final do capitalismo deve preceder a emergência de qualquer configuração social que mereça o nome de alternativa, então as alternativas necessitam concorrer para a queda do capitalismo antes mesmo de existirem, salvo se o capitalismo pretensamente vier a cair sozinho, à revelia dos embates sociais. Essa contradição lógica subsiste por causa de um bloqueio epistemológico da razão crítica moderna que, entre outras dificuldades apontadas por Santos (1999), concebe a sociedade como uma totalidade e, assim, não consegue visualizar e propor senão uma alternativa total à sociedade que existe, como se no momento de transição que vivemos essa alternativa pudesse existir.

As dialéticas se estabelecem em diferentes temporalidades. Referindo-se aos tempos históricos, Braudel advertia quanto ao ingresso da modernidade num período de crise secular muito longo, cujo amadurecimento e desfecho ultrapassariam a primeira metade deste século, tal como a crise dos cem anos entre 1350 e 1450 (apud Gómez de Souza, 2000: 241). Seja como for, entender a transição à luz dos fatos, tanto mais na intenção de direcioná-la ou abreviá-la, requer em nosso caso sopesar o sentido das manifestações

\footnotetext{
${ }^{9}$ Nessa lógica, o que pensar do movimento feminista, que contribuiu para introduzir as mulheres no mercado de trabalho e de consumo; ou do sindicalismo, que além de controlar (ao organizar) os trabalhadores, induziu a aceleração das inovações tecnológicas como motor da produtividade e a conversão da mais-valia relativa no principal mecanismo de acumulação do capital no interior do processo produtivo?
} 
históricas de solidarismo entre os trabalhadores, considerando os seus momentos de expansão e a sua permanência ao longo do tempo como um dos elementos constituintes da sociedade erigida desde o século XIX.

É manifesto que as ondas associativistas relacionam-se com a evolução do capitalismo e com o movimento pendular entre o mercado e o Estado. A ausência inicial do Estado social e sua crise posterior incrementaram o desamparo dos trabalhadores e, por conseguinte, sua necessidade de forjarem instrumentos de sobrevivência, criando novas fórmulas ou recorrendo a sistemas anteriores, em desuso mas não esquecidos. Tem sido assim desde que o sistema econômico hegemônico classificou gradativamente os indivíduos, segundo sua quota de capital e sua capacidade de trabalho, conforme os trunfos de que dispunham para participarem da produção de mercadorias. As ações de acomodamento, as lutas de contestação e as estratégias individuais dos trabalhadores refletem a má sorte daqueles que, contra sua vontade e seus sonhos, encontraram-se despojados de outro bem de valia senão sua força física e intelectual, posta a serviço do imperativo de reprodução ampliada do capital.

A conjuntura atual da Economia Solidária assinala um período em que as formas clássicas de resistência dos trabalhadores, pela via dos afrontamentos de classe, pela reclusão em modos de vida tradicionais e por tentativas de entrar individualmente no jogo, em busca de um lugar ao sol, mostram-se impotentes. Observa-se então o ressurgimento da outra alternativa, que em verdade foi acionada pelos trabalhadores desde os primórdios de sua luta contra a submissão ao capital e que jamais arrefeceu de todo, embora tenha conhecido duras derrotas e desvirtuamentos, além de períodos de perda de força e de quase hibernação.

As vagas de solidarismo refletem os pontos altos da curva de mobilização dos trabalhadores. Mas não explicam adequadamente a mobilização em si, isto é, as necessidades e as aspirações que a motivam, nem os significados que o seu atendimento por via da solidariedade veio a ter, para os seus protagonistas diretos e por seus impactos sobre o sistema social. Ademais, nas fases de refluxo a curva não estacionou no nível zero de mobilização. $\mathrm{O}$ recurso à reciprocidade e à participação reflete uma condição de vontade, veiculando um duplo desejo emancipatório dos trabalhadores: do trabalho alienado ao capital e da sociabilidade pobre oferecida pelo utilitarismo real, isto é, aquele decorrente da lógica implacável da mercadoria e não do bem-estar filosoficamente visionário dos seus formuladores. Não basta aos trabalhadores estarem acuados. Será o seu lastro de experiências positivas e sua capacidade de idealização que tornarão a alternativa solidária atrativa e viável (Gaiger, 2004b). A luta dos trabalhadores em face do desafio gigan- 
tesco trazido por sua preferência pela autogestão, da qual se tem exemplos recentes (Kleiman, 2008), demonstra como outro espírito sobrevive e alimenta a nossa civilização.

A solidariedade garantiu a preservação de outras modalidades de produção material da vida. Diversas economias produtivas e orientadas ao intercâmbio de bens existiam antes da disseminação das relações capitalistas, de modo que essas representaram, a rigor, a introdução de outra economia, gradativamente sobreposta às formas pré-existentes. As organizações integralmente forjadas em princípios de reciprocidade e cooperação disseminaram-se apenas em certos momentos, como cachos, seguindo ciclos de expansão e retração. Todavia, seu significado histórico é bem maior, uma vez que o solidarismo se insere no espectro amplo dos movimentos que traçaram os parâmetros éticos e morais cobrados pela civilização para seguir legitimando o seu sistema econômico, como se observa hoje claramente na agenda dos movimentos altermundialistas.

Pode-se admitir a hipótese de que a Economia Solidária promove valores altruístas no interior de uma axiologia não anti, mas meta-utilitarista. Ela não rejeita o cálculo de interesse próprio e as relações de intercâmbio, apenas por estarem despojados de qualquer intenção de criar vínculos, pois tais relações se limitam precisamente à troca e nisso são funcionais, além de preservarem a individualidade das partes que transacionam. Ademais, a Economia Solidária valoriza as relações de comensalidade típicas da economia familiar e doméstica, mas percebe seus limites quando se trata de estruturar iniciativas fundadas em relações de cooperação mutuamente consentidas pela via democrática. O princípio reciprocitário contido na Economia Solidária atualizaria então o esquema quadripolar de Polanyi (1980), ao mesmo tempo em que transbordaria as suas fronteiras iniciais, incidindo sobre os demais princípios do comportamento econômico: sobre o interesse próprio, ao pleitear a simetria nas relações de intercâmbio; sobre a obrigação, ao estimular a implicação consciente e voluntária em prol do bem comum; sobre o costume, ao valorizar a liberdade entre iguais.

Entre as visões mais entusiasmadas, a Economia Solidária é associada quase invariavelmente a um novo projeto de sociedade. Nesse particular, cabe um último reparo, considerando a sutil e freqüente inversão de termos observada entre os defensores da Economia Solidária: no lugar das novas experimentações e práticas efetivas, coloca-se a sua representação ideológica e política post factum, intelectualmente idealizada, como sendo o elemento motriz primordial. Um exercício tipicamente iluminista, em contradição frontal com a filosofia da práxis de Marx, converte o projeto na razão de ser das práticas, em seu elemento teleologicamente orientador e politicamente 
classificador. Esse trato intelectualista das demandas da Economia Solidária já mostrou seus riscos no Norte, ao transformá-la em assunto de especialistas e torná-la cativa do aparelho institucional. No Sul, os bloqueios da via institucional tendem a valorizar o papel dos agentes mediadores, sobretudo quando os mesmos se outorgam a clarividência dos fins a perseguir, o que tende a subordinar os fatos a suas concepções e interesses corporativos.

É preciso que os novos protagonistas possam guiar-se pela experiência, sem que a mesma seja tolhida por esquemas de pensamento extemporâneos e infecundos. A pauperização e a opressão cotidianas alimentam as reivindicações e as novas formas de organização popular quando há ensaios em marcha, nos quais a energia contida nas idealizações e as relações de confiança jogam um papel decisivo. Em nossos dias, as tentativas de resistir ao despotismo do capital e de humanizar a civilização ocorrem no contexto de uma transição mundial complexa, que assusta ao parecer não ter fim, na qual há carência de estruturas sociais reconfortantes, de papéis sociais definidos e de um novo projeto de sociedade. Em tal condição histórica, como recorda Dubet (2004), a experiência converte-se na chave da dinâmica psicossocial. Ela impulsiona os indivíduos ao agir e a construírem cenários de vida significativa.

\section{Referências bibliográficas}

Bell Lara, José (1997), "Informalisation et nouveaux agents économiques: Le cas de l'Amérique Latine", Alternatives Sud, 4(2), 19-39.

Bourdieu, Pierre (1963), "La société traditionnelle : Attitude à l'égard du temps et conduite économique", Sociologie du Travail, 1, 24-44.

Caillé, Alain; Laville, Jean-Louis (1996), "Pour ne pas entrer à reculons dans le XXI siècle", Extrait du débat, 89, 80-89.

Chopart, Jean-Noël et al. (orgs.) (2006), Les dynamiques de l'économie sociale et solidaire. Paris: La Découverte.

Coraggio, José (2007), "Una perspectiva alternativa para la economía social: de la economía popular a la economia del trabajo", in José Coraggio (org.), La economía social desde la periferia: contribuciones latinoamericanas. Buenos Aires: Altamira, 165-194.

Defourny, Jacques (1998), "La longue marche du concept d'économie sociale", Reflets et perspectives de la vie économique, 37(4), 5-19.

Defourny, Jacques (2005), "Économie sociale", in Jean-Louis Laville; Antônio Cattani (orgs.), Dictionnaire de l'autre économie. Paris: Desclée de Brouwer, 233-241.

Defourny, Jacques et al. (orgs.) (1999), L'économie sociale au Nord et au Sud. Paris/Bruxelles: De Boek.

Dubet, François (1994), Sociologie de l'expérience. Paris: Seuil. 
Evers, Adalbert; Laville, Jean-Louis (orgs.) (2004), The Third Sector in Europe. Cheltenham (UK)/Northampton (USA): Edward Elgar.

Fernandes, Rúbem (1994), Privado, porém público: O Terceiro Setor na América Latina. Rio de Janeiro: Relume-Dumará.

Gaiger, Luiz (2004a), "A economia solidária e o projeto de outra mundialização", DADOS - Revista de Ciências Sociais, 47(4), 799-834.

Gaiger, Luiz (org.) (2004b), Sentidos e experiências da economia solidária no Brasil. Porto Alegre: UFRGS.

Gaiger, Luiz (2005), "Economie solidaire et espace public; quelques remarques à propos du rôle des agents médiateurs", in Jean-Louis Laville et al. (orgs.), Action publique et économie solidaire: Une perspective internationale. Ramonville Saint-Agne: Editons Ères.

Gaiger, Luiz (2006), “A racionalidade dos formatos produtivos autogestionários”, Sociedade e Estado, 21(2), 513-44.

Gaiger, Luiz (2007a), “A outra racionalidade da economia solidária. Conclusões do primeiro Mapeamento Nacional no Brasil”, Revista Crítica de Ciências Sociais, 79, 57-77.

Gaiger, Luiz (2007b), "La economía solidaria y el capitalismo en la perspectiva de las transiciones historicas", in José Coraggio (org.), La economía social desde la periferia: contribuciones latinoamericanas. Buenos Aires: Altamira, 79-109.

Gaiger, Luiz (2007), “Nouvelles formes de production non capitaliste au Brésil”, Tiers Monde, 190, 309-324.

Gómez de Souza, Luiz (2000), "Para se discutir uma economia dos setores populares: perguntas que ficam”, in Gabriel Kraychete et al. (orgs.), Economia dos setores populares: entre a realidade e a utopia. Petrópolis: Vozes, 225-243.

Kleiman, Fernando (2008), Lições de Catende; a construção de uma autogestão em Pernambuco. São Paulo: Annablume.

Laville, Jean-Louis (2004) (org.), Economía social y solidaria. Una visión europea. Buenos Aires: Altamira.

Lisboa, Armando (1999), Empresa cidadã: Nova metamorfose do capital?. Florianópolis: UFSC.

Nyssens, Marthe (org.) (2006), Social Enterprise. Abingdon/New York: Routledge.

Polanyi, Karl (1980), A grande transformação. Rio de Janeiro: Campus.

Razeto, Luis (1990), Las empresas alternativas. Montevidéu: Editorial Nordan-Comunidad.

Santos, Boaventura de Sousa (1999), "Porque é tão difícil construir uma teoria crítica?", Revista Crítica de Ciências Sociais, 54, 197-215.

Santos, Boaventura de Sousa (org.) (2002), Produzir para viver. Os caminhos da produção não capitalista. Rio de Janeiro: Civilização Brasileira.

Veronese, Marília (2008), Psicologia social e economia solidária. Aparecida: Idéias \& Letras. 